\title{
Walkie talkies to aid health care workers' compliance with personal protective equipment in the fight against COVID-19
}

\author{
Dominic Fenn ${ }^{1,2^{*}}$ (D) Jonny Coppel ${ }^{1,3}$, Jessica Kearney ${ }^{1,4}$, Lucy Everson ${ }^{1,5}$, Simon Braithwaite ${ }^{1,6}$ and \\ Rahul Chodhari ${ }^{1,7}$
}

\section{Dear Editor}

The recent article by Houghton et al. in the Cochrane Database of Systematic Reviews highlighted some key limitations associated with health care workers' compliance with infection prevention and control (IPC) guidelines [1]. Addressing barriers highlighted by this review is crucial to keep healthcare workers and patients safe during the SARS-CoV-2 pandemic.

They identify that the practicalities of donning and doffing personal protective equipment (PPE) are a barrier to adherence. They recognise this process as timeconsuming and detrimental to healthcare workers' health [1]. However, we wanted to draw the readers' attention to another barrier created by PPE. Whilst wearing full PPE, communication between COVID and nonCOVID designated areas becomes a challenge [2].
Firstly, phones and pagers are difficult to access or cannot be used due to contamination risk. Secondly, staff must remove PPE when moving from one clinical area to another. This both delays communication and serves as an additional drain on precious PPE resources [1].

What can be done? One approach is to use walkie talkies. Liew et al. draw attention to their use in Singapore [3]. They provide a quick, resource-efficient and effective means of communicating and may provide a solution. At our charity, Asthma Innovation Research (AIR), we recognised the potential of walkie talkies through the team's personal experience and have subsequently supplied over 75 hospitals across the UK. Nevertheless, while they have several attributes that make them suitable for use during the current pandemic, there are limitations that must be acknowledged and

Table 1 Advantages and disadvantages of walkie talkie use in health care settings

\begin{tabular}{|c|c|}
\hline Advantages & Disadvantages \\
\hline Low cost & Non-secure channel \\
\hline Easy to decontaminate per IPC guidance & Miscommunication between multiple teams sharing the same channel \\
\hline Simple to operate & $\begin{array}{l}\text { Radio frequencies may be obstructed by hospital structures (e.g. lead lining within } \\
\text { radiotherapy departments) }\end{array}$ \\
\hline Can be used while wearing PPE & Specific communication approach required \\
\hline \multicolumn{2}{|l|}{ Does not rely on telecommunication infrastructure } \\
\hline $\begin{array}{l}\text { "One to many" communication provides instant access to } \\
\text { the whole team }\end{array}$ & \\
\hline
\end{tabular}

\footnotetext{
* Correspondence: dominicfenn@gmail.com

'Asthma Innovation Research, London, UK

${ }^{2}$ Department of Respiratory Medicine, Amsterdam UMC, Amsterdam, The Netherlands

Full list of author information is available at the end of the article
}

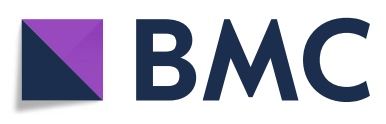

(C) The Author(s). 2020 Open Access This article is licensed under a Creative Commons Attribution 4.0 International License, which permits use, sharing, adaptation, distribution and reproduction in any medium or format, as long as you give appropriate credit to the original author(s) and the source, provide a link to the Creative Commons licence, and indicate if changes were made. The images or other third party material in this article are included in the article's Creative Commons licence, unless indicated otherwise in a credit line to the material. If material is not included in the article's Creative Commons licence and your intended use is not permitted by statutory regulation or exceeds the permitted use, you will need to obtain permission directly from the copyright holder. To view a copy of this licence, visit http://creativecommons.org/licenses/by/4.0/ The Creative Commons Public Domain Dedication waiver (http://creativecommons.org/publicdomain/zero/1.0/) applies to the data made available in this article, unless otherwise stated in a credit line to the data. 
Table 2 Current and future solutions to key disadvantages of walkie talkie use in health care settings

\begin{tabular}{|c|c|c|}
\hline Issue & Current solution & Future solutions \\
\hline Non-secure channel & $\begin{array}{l}\text { - Avoid patient identifiable information } \\
\text { - Frequency hopping: a coordinated channel switch } \\
\text { by the team arranged off an open channel }\end{array}$ & $\begin{array}{l}\text { - Investment into secure radio systems } \\
\text { that use: } \\
\text { Encrypted frequencies } \\
\text { Automatic frequency-hopping }\end{array}$ \\
\hline $\begin{array}{l}\text { Miscommunication between multiple teams } \\
\text { sharing the same channel }\end{array}$ & $\begin{array}{l}\text { - If more than one different department using walkie } \\
\text { talkies, department heads should establish which } \\
\text { channel to use for each team to keep communications } \\
\text { separate. }\end{array}$ & \\
\hline $\begin{array}{l}\text { Radio frequencies may be obstructed by } \\
\text { hospital structures (e.g. lead lining within } \\
\text { radiotherapy departments) }\end{array}$ & $\begin{array}{l}\text { - To be aware of signal loss zones and make sure } \\
\text { alternative means of communication are available }\end{array}$ & $\begin{array}{l}\text { - Increased transmission power of radio } \\
\text { (requires listened frequencies) } \\
\text { - Use of radio repeater }\end{array}$ \\
\hline Specific communication approach required & $\begin{array}{l}\text { - Communication should be clear, structured and } \\
\text { succinct. It must be obvious who you are and who } \\
\text { you are trying to contact. For example: } \\
\text { "Person A: This is Person A calling Person B, come in } \\
\text { Person B, over ...." } \\
\text { "Person B: This is Person B receiving over ... .." }\end{array}$ & $\begin{array}{l}\text { - Teaching on use of walkie talkie } \\
\text { communication and etiquette as part of } \\
\text { departmental staff induction } \\
\text { - Simulation training to incorporate walkie } \\
\text { talkies }\end{array}$ \\
\hline
\end{tabular}

addressed (Tables 1 and 2). For example, one of the most attractive advantages is also the biggest shortcoming: Commercially available walkie talkies are licencefree and are not dependent on pre-existing telecommunication infrastructure. Therefore, they can be rapidly deployed with no additional costs and allow for timely integration into practice. However, this makes them vulnerable to data breach as the channel may be disrupted by non-health care professionals. Thankfully, awareness of this issue and proactive mitigation can significantly reduce this risk (Table 2). Although walkie talkies may not be a perfect system, they provide a much needed immediate solution. However, preparations for further pandemics should be made, addressing these limitations (Table 2).

Adherence to correct IPC guidance is crucially important during the current pandemic, in addition to effective communication. Walkie talkies are a potential method of enabling timely, coordinated and safe care for patients, while also protecting patients and staff.

\section{Acknowledgements}

Not applicable

\section{Authors' contributions}

DF drafted and conceptualised the main letter. JC, JK and LE re-drafted and proof-read contents of the letter and table. SB and RC proof-read the contents of the letter and table. The authors read and approved the final manuscript.

Funding

Not applicable

Availability of data and materials

Not applicable

Ethics approval and consent to participate

Not applicable
Consent for publication

Not applicable

\section{Competing interests}

The authors have no conflicts of interest to declare in relation to the content of this letter.

\section{Author details}

${ }^{1}$ Asthma Innovation Research, London, UK. ${ }^{2}$ Department of Respiratory Medicine, Amsterdam UMC, Amsterdam, The Netherlands. ${ }^{3}$ Department of Intensive Care, Royal Free Hospital, Barnet site, London, UK. ${ }^{4}$ Department of Medicine, Kings College Hospital, London, UK. ${ }^{5}$ Department of Obstetrics and Gynecology, Southmead Hospital, Bristol, UK. ${ }^{6}$ Department of Radiology, John Radcliff Hospital, Oxford, UK. Department of Paediatrics, Royal Free Hospital, London, UK.

Received: 10 June 2020 Accepted: 3 July 2020

Published online: 13 July 2020

References

1. Houghton C, Meskell P, Delaney H, Smalle M, Glenton C, Booth A, Chan XHS, Devane D, Biesty LM. Barriers and facilitators to healthcare workers adherence with infection prevention and control (IPC) guidelines for respiratory infectious diseases: a rapid qualitative evidence synthesis. Cochrane Database of Syst Rev. 2020;4(4):CD013582.

2. Liew MF, Siow WT, MacLaren G, See KC. Preparing for COVID-19: early experience from an intensive care unit in Singapore. Crit Care. 2020;24(1):83.

3. Sevastru S, Curtis S, Emanuel Kole L, Nadarajah P. Failure modes and effect analysis to develop transfer protocols in the management of COVID-19 patients [published online ahead of print, $2020 \mathrm{Apr}$ 27]. Br J Anaesth. 2020; S0007-0912(20):30270-1.

\section{Publisher's Note}

Springer Nature remains neutral with regard to jurisdictional claims in published maps and institutional affiliations. 